Proc. Estonian Acad. Sci. Biol. Ecol., 2002, 51, 3, 184-203

\title{
Meiobenthos in some Estonian small stratified lakes
}

\begin{abstract}
Tarmo Timm
Võrtsjärv Limnological Station, Institute of Zoology and Botany, Estonian Agricultural University, 61101 Rannu, Tartumaa, Estonia; ttimm@zbi.ee

Received 8 January 2002, in revised form 18 March 2002

Abstract. At least 120 animal taxa were found in the corer samples taken from sediment in contact with the metalimnion and adjacent water layers in 10 small Estonian lakes. The bulk of them belonged to small individuals of macrobenthic taxa (pseudomeiobenthos) or to plankton. The proportion of eumeiobenthos (Nematoda, Turbellaria, Hydra, Ostracoda, Harpacticoida), and even their frequency, were low. Inclusion of meiobenthic animals found on the sieve with a mesh size of $0.15 \mathrm{~mm}$ increased the abundance of total zoobenthos by an order of magnitude compared with the abundance of the macrobenthos picked out without any magnification. Their contribution to the biomass, on the contrary, was insignificant. No distinct metalimnion-related peculiarities were found in zoobenthos. The diversity, number, and biomass of animals usually decreased with increasing depth, although differences were observed for different lakes and years. Only planktic cyclopoids, which spend some part of their life in bottom sediment, were sometimes very abundant at various depths, including the anoxic profundal. Cyclopoids were most often the dominant group in meiobenthos. Among the studied lakes, the poorest both in macro- and meiobenthos was Lake Holstre Linajärv. Lake Verevi was the richest in 1999-2000, in the period of the reconstruction of a swimming pool. A similar taxonomic content and depth distribution of meiobenthos have been found in several lakes of Latvia and Belarus. Northwards, in the small lakes of the Karelian Isthmus and Finland, as well as in some less stratified Masurian lakes, the share of eumeiobenthos is much higher, not to mention Lake Ladoga. In neighbouring large Lake Pihkva (Pskovskoe), eumeiobenthos is very rich on sandy bottom while pseudomeiobenthos becomes more important on mud.
\end{abstract}

Key words: fauna, zoobenthos, abundance, biomass, small lake, stratification, depth zone.

\section{INTRODUCTION}

Under meiobenthos we refer here to small benthic metazoans usually ignored in ordinary zoobenthos samples, either because they escape a coarse sieve, or are invisible without magnification. The term was coined in the middle of the 20th century, first as a synonym of the "interstitial fauna" inhabiting coarse marine sand 
(Higgins \& Thiel, 1988). The words "microbenthos" and "mesobenthos" have been used with the same meaning, to distinguish them from macrobenthos, i.e. bottom animals that are distinctly visible without any magnification (e.g. Babitskij, 1980). Delimitation of macro- and meiobenthos is conventional. The latter can include animals not caught with a sieve of certain mesh size (e.g., $1 \mathrm{~mm}$ ), animals of certain size (e.g., 0.1-1 mm long, or up to 2-3 mm long, or weighing 0.0001$0.05 \mu \mathrm{g}$ ), or some animal groups (e.g., free-living nematodes, lower crustaceans, etc.) usually ignored in ordinary benthic samples. Depending on collecting methods, some larger protozoans with obvious cases can be included into meiobenthos (Elmgren, 1973; Babitskij, 1980); otherwise even metazoan rotifers can be lost when preserved. A comprehensive historical survey is given by Kurashov (1994).

In Estonia, the only available investigations on meiobenthos are represented by short notes on the "microbenthos" of Lake Pihkva (Pskovskoe), compiled by Mikhajlov (1970, 1973). Some meiobenthic animals have been included in ordinary samples of macrozoobenthos from the Baltic Sea and from rivers, when sorted under magnification (e.g. Järvekülg, 1979). In the neighbouring countries, rich meiobenthos was found in the profundal of large lakes in Finland, as well as in Lake Ladoga (Paasivirta \& Särkkä, 1978; Särkkä, 1992, 1993, 1995, 1999). There exist papers on the meiobenthos of smaller lakes of the Karelian Isthmus (Skvortsov, 1984; Petukhov, 1999), eastern Latvia (Kurashov \& Belyakov, 1987), and Belarus (Babitskij, 1980), as well as on large Lake Mälaren in Sweden (Milbrink, 1969).

This is the first study dealing with the amount and qualitative content of meiobenthos in small Estonian lakes. It was launched in the framework of the project "The influence of stratification on the circulation of biological matter in the lake ecosystem", carried out by the Võrtsjärv Limnological Station of the Institute of Zoology and Botany at the Estonian Agricultural University in 19982002. Therefore sampling was limited mostly to the transition zone between the littoral and the profundal, covered with the water of metalimnion during the summer stratification. The littoral zone per se was not studied.

\section{MATERIAL AND METHODS}

Sampling was performed in July-August 1998 and 1999 on ten small stratified lakes in South-East Estonia (Holstre, Holstre Linajärv, Tsolgo Mustjärv, Pindi Kärnjärv, Peta, Kooraste Linajärv, Nohipalu Valgjärv, Verevi, Vellavere Külajärv, and Kaussjärv), as well as seasonally (May, June, August, and October) in 2000 and once (August) in 2001 on Lake Verevi only. The lakes have a surface area of 1.7-12.6 ha and a maximum depth of 11.0-29.7 m. Most of them belong to the eutrophic or even hypereutrophic type, being contaminated either with former flax-retting or other agricultural pollution. Lake Verevi has been polluted with urban runoffs from the small town of Elva, and temporarily (1999) disturbed 
with construction work of a large swimming pool. Lake Nohipalu Valgjärv is still more or less oligotrophic (the only lake with less than $100 \mathrm{mg} \mathrm{m}^{-3}$ of total phosphorus in the hypolimnion), while Lake Pindi Kärnjärv belongs to the dyseutrophic (mixotrophic) type. Siderotrophic Lake Kaussjärv, fed with cool spring water rich in iron and carbonates, is better buffered than the others. All of the studied lakes have a small watershed, steep slopes, and are sheltered from the wind. The thermocline was $1-3 \mathrm{~m}$ thick and was usually located at depths between 2.5 and $4.5 \mathrm{~m}$ in more eutrophic lakes but between 3.5 and $6 \mathrm{~m}$ in the most transparent lakes of Nohipalu Valgjärv and Kaussjärv. The thermocline was usually accompanied with the oxycline at the sampling time. However, sometimes the latter appeared already in the epilimnion, while in other cases a maximum content of oxygen was observed in the metalimnion. The hypolimnion was more or less anoxic in summer. Bottom sediments were muddy, sometimes mixed with plant debris or fine sand. The littoral (the zone of macrovegetation) changed directly into the profundal, without any distinct sublittoral zone. The metalimnion was usually in contact with the uppermost part of the profundal.

Three triple samples were taken from the near-shore bottom slope in each lake, at depths corresponding to the lower boundary of the epilimnion, the metalimnion (thermocline), and the upper boundary of the hypolimnion at the time of sampling. In Lake Verevi, the sampling sites were located at fixed depths of 2, 3, and $4 \mathrm{~m}$, corresponding to the summer stratification of water, and an extra station was set up in the deeper profundal, at a depth of $6 \mathrm{~m}$ in 2000 and 2001. Thus a total of 80 samples were collected from ten lakes in 1998-2001. Sampling in the field was performed by Henn Timm.

A $52 \mathrm{~cm}$ high metallic corer with a grasp area of $6.38 \mathrm{~cm}^{2}$ was used. Every sample consisted of three replicas, with a total surface of $1 / 522.5 \mathrm{~m}^{2}$. The sampled sediment was preserved immediately by adding a small amount of formaline. In the laboratory, every replica was washed separately under tap water on two silk sieves with a mesh size (not considering thread thickness) of 0.4 and $0.15 \mathrm{~mm}$. Sieve residues were studied using a Bogorov counting plate and $\times 16$ magnification. The animals were picked out, measured, and the bigger ones (corresponding to macrozoobenthos) were weighed on a torsion balance with up to $1 \mathrm{mg}$ accuracy. The wet weight of the smaller animals was calculated indirectly.

The body volume of cylindrical animals (mainly chironomid larvae and oligochaetes) was calculated in cubic millimetres from their length and mean diameter, and was treated as being roughly equal to their wet weight in milligrams. (Similar, although a more sophisticated, procedure was used on these animals by Smit et al. (1993)). The calculated weight was compared with the actual weight in larger individuals, and a good accordance was found. In chironomids $(n=47)$, the ratio of the calculated to the weighed data was $1.08 \pm \mathrm{SE} 0.07$; and in oligochaetes $(n=55) 1.02 \pm$ SE 0.08 . In the smallest pea clams, half of the volume of a sphere with a diameter corresponding to shell height was used for the same purpose. The wet weight of the nematodes and crustaceans was calculated using standard tables (Kurashov, 1994, et al.). 
Both the abundance and wet biomass of animals per square metre were calculated using the coefficient 522.5. Most specimens, including many of the smallest nematodes and crustaceans, always remained on a $0.4 \mathrm{~mm}$ sieve. The animals of both fractions were pooled in calculations, as well as data of three replicas in every sample.

Oligochaeta were identified by the author; Chironomidae, by Külli Kangur; some other macrobenthic animals, by Henn Timm; Ostracoda, by Arvi Järvekülg; lower crustaceans (Cladocera, Calanoida, Cyclopoida), by Aare Mäemets (all from the Institute of Zoology and Botany); and Nematoda, by S. Ya. Tsalolikhin (Zoological Institute in St. Petersburg).

At the same stations, samples of macrozoobenthos were taken with a Borutskij grab $\left(225 \mathrm{~cm}^{2}, 5\right.$ replicas); the animals were picked out without magnification and fixed in ethanol. Thus it was possible to compare the data obtained with two sampling methods. A large number of taxa were common for both series but their size range was larger for corer samples. The latter included, besides eumeiobenthos and plankton, also individuals of macrozoobenthos, both large and small. The smallest young specimens (pseudomeiobenthos) usually remain unnoticed in ordinary bottom grab material. They were treated here under the category "macrozoobenthos" or "large animals", together with the larger conspecific individuals (Table 1), since no reasonable criterion was available for their formal separation. Some quantitative aspects of both macro- and meiozoobenthos in these lakes are discussed elsewhere by Timm et al. (in press).

Table 1. Average abundance and biomass of animals in the corer samples from 10 lakes in 1998-99

\begin{tabular}{|c|c|c|c|c|c|c|}
\hline \multirow[b]{2}{*}{ Animal group } & \multicolumn{2}{|c|}{ Epilimnion } & \multicolumn{2}{|c|}{ Metalimnion } & \multicolumn{2}{|c|}{ Hypolimnion } \\
\hline & \begin{tabular}{|c|}
$\begin{array}{c}\text { Abundance, } \\
\text { ind. } \mathrm{m}^{-2}\end{array}$ \\
\end{tabular} & \begin{tabular}{|c|} 
Biomass, \\
$\mathrm{g} \mathrm{m}^{-2}$
\end{tabular} & $\begin{array}{c}\text { Abundance, } \\
\text { ind. } \mathrm{m}^{-2}\end{array}$ & $\begin{array}{c}\text { Biomass, } \\
\mathrm{g} \mathrm{m}^{-2}\end{array}$ & $\begin{array}{c}\text { Abundance, } \\
\text { ind. } \mathrm{m}^{-2}\end{array}$ & $\begin{array}{c}\text { Biomass, } \\
\mathrm{g} \mathrm{m}^{-2}\end{array}$ \\
\hline Chironomidae & 1568 & 3.076 & 679 & 0.390 & 209 & 0.564 \\
\hline Oligochaeta & 6923 & 2.319 & 3422 & 3.251 & 706 & 0.588 \\
\hline Mollusca & 261 & 0.158 & 157 & 0.326 & & \\
\hline Chaoborus & & & 52 & 0.339 & 156 & 0.679 \\
\hline Other groups & 417 & 0.487 & 235 & 1.855 & 26 & 0.032 \\
\hline Total macrozoobenthos & 9169 & 6.040 & 4545 & 6.161 & 1097 & 1.863 \\
\hline Nematoda & 1385 & 0.005 & 261 & $<0.001$ & 418 & 0.001 \\
\hline Turbellaria & 182 & 0.007 & 104 & 0.035 & & \\
\hline Hydra & 26 & 0.001 & 26 & 0.001 & & \\
\hline Ostracoda & 418 & 0.020 & 967 & 0.043 & 52 & 0.008 \\
\hline Harpacticoida & & & 26 & $<0.001$ & 26 & 0.001 \\
\hline Total eumeiobenthos & 2011 & 0.033 & 1384 & 0.080 & 496 & 0.010 \\
\hline Cladocera & 967 & 0.040 & 548 & 0.026 & 365 & 0.033 \\
\hline Calanoida & 339 & 0.011 & 1463 & 0.043 & 679 & 0.022 \\
\hline Cyclopoida & 4023 & 0.124 & 4337 & 0.160 & 18052 & 0.768 \\
\hline Total of planktic animals & 5329 & 0.175 & 6348 & 0.229 & 19096 & 0.823 \\
\hline Total of "sm & 7340 & & 7732 & 0.309 & 19592 & 0.833 \\
\hline Total of all animals & 16509 & 6.248 & 12277 & 6.470 & 20689 & 2.696 \\
\hline
\end{tabular}




\section{RESULTS \\ Qualitative content of the samples}

Altogether, 120 species or higher taxa were identified in the corer samples from 10 lakes (Appendix). Most of them, 71, are of meiobenthos size when young (pseudomeiobenthos) but assume macrozoobenthos size when adult (Chironomidae, Oligochaeta, Mollusca, etc.). Some species (26) are, in fact, planktonic crustaceans (Cladocera, Calanoida, Cyclopoida), but they spend some time, accidentally or regularly, near or inside bottom. Only 23 species belong to permanent small bottom animals, the eumeiobenthos (Nematoda, Turbellaria, Hydra, Ostracoda, Harpacticoida).

Among the "large" animals or macrozoobenthos, Oligochaeta were the most diverse, with 30 species. Only two of them were frequent and abundant: Potamothrix hammoniensis (found in 8 lakes) and Limnodrilus hoffmeisteri (6 lakes). There occurred several small rare forms, such as Amphichaeta leydigi in Lake Verevi and Vejdovskyella macrochaeta in Tsolgo Mustjärv. The latter was found for the first time in Estonia. In 1999-2000, an explosive increase in uncommon Ilyodrilus templetoni and tiny Pristina aequiseta f. foreli was observed in Lake Verevi. In the Borutskij grab samples, taken simultaneously from the same lakes, only 14 oligochaete species were found.

Chironomidae were frequent but not abundant in the cores. Among no less than 24 larval forms, Tanytarsus spp. were the most common, followed by Cladotanytarsus gr. mancus and Procladius choreus. Like in the case of the oligochaetes, 2/3 of the taxa were represented in only one or two samples. In Lake Vellavere Külajärv no chironomids were caught with a corer. Among the other macrozoobenthic animals, unidentified Pisidiidae, as well as larvae of Chaoborus flavicans and Ceratopogonidae were not rare.

Eumeiobenthos was most often represented by scarce small Nematoda (in 16 samples from 7 lakes), with eight species. Higher abundance, dominated by Dorylaimus stagnalis, was repeatedly recorded in Lake Verevi only. In the profundal of oligotrophic Lake Nohipalu Valgjärv, a rare northern nematode species Paramononchus alimovi was found. Ostracoda, with 12 species, were encountered in six lakes, mostly in Kaussjärv, Pindi Kärnjärv, and in 2001 also in all zones of Lake Verevi. Small Turbellaria as well as Hydra sp. occurred seldom and singly. Only two individuals of Harpacticoida were found, both in Lake Tsolgo Mustjärv.

Planktic crustaceans formed the bulk of "small" animals in the corer samples. Almost each sample and replica revealed Cyclopoida, usually as numerous copepodites which were often accompanied also by several full-grown individuals. Seven taxa were identified among them. Mesocyclops leuckarti (in 36 samples from all 10 lakes) occupied the first place, followed by Eucyclops sp. (9 samples, 6 lakes), Mesocyclops oithonoides (6 samples, 3 lakes), and Acanthocyclops viridis (5 samples, 2 lakes). Calanoids of the genus Eudiaptomus (either E. gracilis 
or E. graciloides) were caught in nine lakes of ten. Cladocerans were also present in the samples from nine lakes, with a total of at least 17 taxa, but mostly as single individuals. Diaphanosoma brachyurum was the commonest species, with five records from four lakes.

\section{Comparison of the abundance and biomass in bottom grab and corer samples}

The average abundance and biomass of "large" animals of macrozoobenthos in the samples, taken simultaneously with the Borutskij bottom grab and with the corer in the ten lakes, were calculated. In all study years (1998, 1999, and 2000), the abundance appeared to be by about an order of magnitude higher in the corer samples $\left(17 \pm 10\right.$ times, being $841 \pm 284$ and $7427 \pm 3165$ ind. $\mathrm{m}^{-2}$, respectively, as an average of three years and three zones; $n=9)$. The average biomass was only slightly ( $1.48 \pm 0.42$ times) higher in the corer samples, $7.305 \pm 2.037$ and $8.977 \pm 3.641 \mathrm{~g} \mathrm{~m}^{-2}$, respectively, as these samples added a number of tiny individuals.

"Small" animals (eumeiobenthos + plankton), studied only in the corer samples, were always more abundant than macrozoobenthos, accounting for $62.4 \pm 6.5 \%$ of the individuals counted. Still, their share in the total biomass of zoobenthos was insignificant, on average $10.7 \pm 4.4 \%$ (Table 1 ).

\section{Comparison of depth zones}

The number of taxa usually decreased with depth (Table 2). The transition zone between the littoral and the profundal, corresponding to the epilimnion, included 95 of the total of 120. In the next zone, corresponding to the metalimnion, 59 taxa were recorded; farther, on the upper boundary of the hypolimnion, 28 taxa occurred. In the deeper profundal of Lake Verevi, studied in 2000-2001, only five species were found (usually Mesocyclops leuckarti and Chaoborus flavicans). A similar tendency can be observed for most animal groups. As an exception, Cyclopoida were more diverse in the zones of the metaand hypolimnion than in the zone of the epilimnion; no larvae of Chaoborus flavicans and Chironomus plumosus, as well as Harpacticoida, were caught in the zone of the epilimnion, either. Species of Ostracoda were found in equal numbers in the zones of the epilimnion and the metalimnion. None of the benthic taxa preferred the zone of the metalimnion.

The abundance and biomass of individual groups through different zones are shown in Table 1. A similar tendency is evident in all four study years: the abundance of the "large" animals decreases towards the deeper zones, except that of Chaoborus. The distribution of total biomass was irregular due to the presence of single occasional large individuals of Chironomidae, Sialis, and Oligochaeta. 
Table 2. Species number in the corer samples taken from different zones

\begin{tabular}{l|c|c|c|c}
\hline \multicolumn{1}{c|}{ Lake } & Epilimnion & Metalimnion & Hypolimnion & All zones \\
\hline Holstre & 7 & 10 & 6 & 19 \\
Holstre Linajärv & 3 & 3 & 3 & 7 \\
Tsolgo Mustjärv & 13 & 8 & 8 & 21 \\
Pindi Kärnjärv & 15 & 14 & 4 & 25 \\
Peta & 16 & 9 & 4 & 19 \\
Kooraste Linajärv & 11 & 1 & 3 & 14 \\
Nohipalu Valgjärv & 13 & 13 & 5 & 23 \\
Verevi (1998-99) & 32 & 19 & 5 & 38 \\
Verevi (1998-2001) & 68 & 34 & 18 & 81 \\
Vellavere Külajärv & 7 & 11 & 3 & 16 \\
Kaussjärv & 14 & 8 & 10 & 24 \\
$\quad$ Total of all lakes & 97 & 65 & 33 & 120
\end{tabular}

The average abundance and biomass of "small" animals were determined by the dominating group Cyclopoida. Thus the values were somewhat higher in the zone of the hypolimnion than in the zone of the metalimnion. In the zone of the epilimnion, the respective figures varied in different years.

\section{Comparison of individual lakes}

The studied lakes differ from each other in their abiotic conditions and biota. The species number for individual lakes is given in Table 2 and the average abundance and biomass numbers are given in Table 3.

Table 3. Average summer abundance and biomass of animals in different lakes, 1998-99

\begin{tabular}{l|c|c|c|c}
\hline \multicolumn{1}{c|}{ Lake } & $\begin{array}{c}\text { Abundance of } \\
\text { macro- } \\
\text { zoobenthos, } \\
\text { ind. } \mathrm{m}^{-2}\end{array}$ & $\begin{array}{c}\text { Abundance of } \\
\text { eumeiobenthos }+ \\
\text { planktic animals, } \\
\text { ind. } \mathrm{m}^{-2}\end{array}$ & $\begin{array}{c}\text { Biomass of } \\
\text { macro- } \\
\text { zoobenthos, } \\
\mathrm{g} \mathrm{m}^{-2}\end{array}$ & $\begin{array}{c}\text { Biomass of } \\
\text { meiobenthos + } \\
\text { planktic animals, } \\
\mathrm{g} \mathrm{m}^{-2}\end{array}$ \\
\hline Holstre & 1305 & 22459 & 0.302 & 0.526 \\
Holstre Linajärv & 435 & 435 & 0.826 & 0.010 \\
Tsolgo Mustjärv & 3570 & 6095 & 5.598 & 0.242 \\
Pindi Kärnjärv & 2090 & 7227 & 4.221 & 0.209 \\
Peta & 5225 & 20115 & 5.635 & 2.649 \\
Kooraste Linajärv & 1654 & 5225 & 3.315 & 0.129 \\
Nohipalu Valgjärv & 2437 & 12190 & 1.411 & 0.695 \\
Verevi & 26124 & 34310 & 11.813 & 1.000 \\
Vellavere Külajärv & 348 & 3047 & 4.652 & 0.177 \\
Kaussjärv & 6182 & 4702 & 9.115 & 0.243 \\
Average of ten lakes & 4937 & 11580 & 4.689 & 0.588
\end{tabular}


In Lake Holstre, at least 19 taxa were found, which is a medium number. The thermocline lay deep (sampling sites at 3.5, 5.5, and $8.5 \mathrm{~m}$ ); the bottom sediment was relatively dense. "Large" animals were scarce, while Cyclopoida were abundant and dominated in all zones.

In Lake Holstre Linajärv the thermocline was located higher (sampling sites at $1.8,2.5$, and $4.5 \mathrm{~m}$ ); the sediment was rich in debris including flax boons. The fauna was extremely poor, consisting of seven taxa only. Mostly single individuals were found, and several samples were empty.

In Lake Tsolgo Mustjärv (sampling sites at 2, 3, and $5 \mathrm{~m}$; mud with abundant wood debris) at least 21 taxa were found. The fauna was relatively diverse in the zones of the epi- and metalimnion, including among others Ostracoda, Turbellaria, and the only record of Harpacticoida in the ten lakes studied. A harpacticoid specimen occurred even in the zone of the hypolimnion. A rare oligochaete, Vejdovskyella macrochaeta, was found for the first time in Estonia. In the zone of the hypolimnion, the bottom fauna was relatively scarce, apart from single large larvae of Chaoborus and Chironomus.

Lake Pindi Kärnjärv (sampling sites at 2.4, 3.3, and 5.5 m; fine mud sediment) yielded fewer macrozoobenthic animals but more plankters and Ostracoda in the cores; the species number reached 25 . The zone of the metalimnion was inhabited by a relatively diverse fauna there; the total biomass was high due to the presence of adult oligochaetes Potamothrix hammoniensis. The zone of the hypolimnion was poor in animals, even in Cyclopoida.

In Lake Peta (sampling sites at 2, 3, and $5 \mathrm{~m}$; mud with some sand in the shallowest zone), 19 taxa were established with "large" animals prevailing. Cyclopoida were very plentiful in the zone of the hypolimnion. No Chaoborus larvae were encountered in the corer samples, although they were caught with the Borutskij grab. Some small nematodes (Tobrilus gracilis) were found once in the zone of the hypolimnion.

Lake Kooraste Linajärv is strongly stratified, with the thermocline located very high (sampling sites at 1.6, 2.5, and $3.7 \mathrm{~m}$; the first of them at the edge of yellow water-lilies; mud with flax boons). The fauna was poor in species (14), greatly limited to the uppermost zone. The zone of the metalimnion displayed either no animals or only Cyclopoida. However, cyclopoids were rather abundant in the anoxic zone of the upper hypolimnion.

Nohipalu Valgjärv is the most oligotrophic and transparent among the studied lakes. Mosses, although mostly dead, occurred even deeper than the deep-located thermocline. The samples were taken at depths of 3,5 , and $7.5 \mathrm{~m}$. The fauna consisted of no less than 23 taxa. Only in this lake Asellus aquaticus was found in the corer samples, both in the zones of the epi- and metalimnion. Chironomidae were represented by a single species, Tanytarsus medius, and Oligochaeta were mostly represented by small phytophilous species. In the zone of the hypolimnion the rare nematode Paramononchus alimovi was found beside planktic crustaceans and Chaoborus. Various cladocerans occurred in the corer samples, including 
an indicator of soft and clean water, Holopedium gibberum. Cyclopoida were represented there mostly by Acanthocyclops viridis instead of Mesocyclops dominating in the other lakes.

Lake Verevi is situated in the town of Elva and is intensively exploited for recreation. Reconstruction of the swimming pool in 1999 was related to a temporary lowering of the water level. Sampling sites were initially located at $1.4,2.3$, and $3.5 \mathrm{~m}$ depth, on sediment changing from muddy sand to mud in the deeper zones. In addition, the lake was studied seasonally in 2000 and once in 2001, at four depths $(2,3,4$, and $6 \mathrm{~m})$. Such abundant material revealed also a diverse fauna with at least 81 taxa (54 "large" and 27 "small"). Zoobenthos became unusually abundant and diverse in all zones there in 1999 and in spring 2000, apparently owing to a moderate contamination from the construction site and the changing water level. Chironomidae and Oligochaeta were represented with many taxa in the zones of the epi- and metalimnion. Two uncommon oligochaete species, Ilyodrilus templetoni and Pristina aequiseta f. foreli, displayed a brief explosion of abundance. Nematoda were more abundant in the zones of the epi- and metalimnion of that lake compared with the other lakes, while Ostracoda became abundant only in 2001. In October 2000 (no counterpart of this season in the other lakes), a copious submerse vegetation developed at the shallowest station, bearing a diverse phytophilous fauna including several gastropods and the bryozoan Cristatella mucedo. Planktonic crustaceans (mostly Mesocyclops leuckarti, but in 1998 also M. oithonoides) were abundant in the deeper zones, particularly in the profundal proper. During 2000-2001, their abundance and biomass gradually recovered the lower level of 1998.

In Lake Vellavere Külajärv, the thermocline lay high (sampling sites at 1.5, 2.5 , and $4 \mathrm{~m}$ ) and mud was rich in peat and sheaths of Cyanobacteria. Only 16 taxa were found, and "large" ones were caught only in two samples of six. The abundance and biomass were low, except for one case when a large larva of Sialis lutaria accidentally fell in the corer. The abundance of "small" animals was low, too. However, various representatives of eumeiobenthos occurred both in the zones of the epi- and metalimnion. Of the cyclopoids, not only Mesocyclops leuckarti but also Acanthocyclops viridis was recorded.

In Lake Kaussjärv the thermocline was located deep enough (sampling sites at $1.6,3$, and $5.5 \mathrm{~m}$, near a small inflow). Mud was rich in soft debris. The fauna was relatively diverse, with at least 24 taxa. Among "large" animals, adult oligochaetes Potamothrix hammoniensis were common in all zones, accompanied by Tubifex tubifex. Such an assemblage is characteristic of eutrophic lakes with mesotrophic features. Chaoborus larvae occurred in the zone of the hypolimnion, while chironomid larvae were scarce and occurred in the upper zones only. Ostracoda were present in all three zones. Nematoda were found both in the zones of the epi- and hypolimnion but only in small numbers. Planktic crustaceans (dominated by Cyclopoida) were scarce, slightly more numerous in the zone of the hypolimnion. 


\section{Comparison of different years}

The abundance and biomass of animals in the corer samples, taken in 1998 and 1999, were different in individual lakes. They do not reveal any clear trends owing to the small number of samples. However, the average abundance and biomass for nine lakes were rather similar in both study years (Table 4). Thus the number of 27 triple samples seems to be sufficient for levelling out occasional differences observed for individual lakes. Lake Verevi was intentionally treated separately from the other nine lakes, as in this lake the abundance and biomass of both "large" and "small" animals increased temporarily by an order of magnitude in all zones in 1999 when the lake was disturbed by the construction activity.

Table 4. Comparison of the average summer abundance and biomass of animals in the corer samples in different years

\begin{tabular}{l|c|c|c|c|c}
\hline & Year & $\begin{array}{c}\text { Abundance } \\
\text { of macro- } \\
\text { zoobenthos, } \\
\text { ind. } \mathrm{m}^{-2}\end{array}$ & $\begin{array}{c}\text { Abundance of } \\
\text { eumeiobenthos }+ \\
\text { plankton animals, } \\
\text { ind. } \mathrm{m}^{-2}\end{array}$ & $\begin{array}{c}\text { Biomass of macro- } \\
\text { zoobenthos, } \\
\mathrm{g} \mathrm{m}^{-2}\end{array}$ & $\begin{array}{c}\text { Biomass of } \\
\text { meiobenthos }+ \\
\text { plankton animals, } \\
\mathrm{g} \mathrm{m}^{-2}\end{array}$ \\
\hline Nine lakes & 1998 & 2592 & 8417 & 4.780 & 0.676 \\
& 1999 & 2573 & 9695 & 3.015 & 0.409 \\
Lake Verevi & 1998 & 3482 & 2090 & 2.896 & 0.080 \\
& 1999 & 48766 & 66531 & 20.730 & 1.920 \\
& 2001 & 4353 & 10798 & 1.383 & 0.511
\end{tabular}

\section{DISCUSSION}

The meiobenthos of small lakes has been repeatedly studied in the neighbouring Leningrad Region of Russia. In deep mesotrophic Lake Verkhnee Vrevo (Zakhodnova et al., 1984), high numbers of abundance and biomass were recorded, $160000-900000$ ind. $\mathrm{m}^{-2}$ and $1.58-21.39 \mathrm{~g} \mathrm{~m}^{-2}$ in different seasons, with a maximum in June. Nematodes formed an overwhelming majority of meiobenthos, with $142000-730000$ ind. $\mathrm{m}^{-2}$ and $0.14-1.05 \mathrm{~g} \mathrm{~m}^{-2}$; their species were different from those found in our study. Ostracods and cyclopoids were abundant too; oligochaetes, chironomids, and tardigrades were less numerous. Although it is not clearly indicated, the study seems to be limited to shallows.

In a paper on the production biology of meiobenthos, the average abundances and biomasses for five small lakes on the Karelian Isthmus are given, measuring from 1200 to 14900 ind. $\mathrm{m}^{-2}$ and from 0.15 to $0.92 \mathrm{~g} \mathrm{~m}^{-2}$ (Skvortsov, 1984). These figures are much smaller than the respective parameters for Lake Vrevo, but they are rather similar to the figures obtained for the Estonian lakes under study; apparently, different depth zones were involved. The author states that the biomass of meiobenthos does not increase in more eutrophied lakes. On the 
contrary, its share in the total benthos decreases in such a case, since oligochaetes predominate over rapidly growing chironomids and cyclopoids.

The best comparative material for our lakes was presented by Petukhov (1999), who studied two small closed lakes on the Karelian Isthmus in 1995-97. Depths of 1, 2, 4, and $8 \mathrm{~m}$ were sampled, at least in one year also seasonally. The position of the thermocline was not established, but strong oxygen deficiency was observed in the profundal, at $8 \mathrm{~m}$. In both lakes, eumeiobenthos was dominated by small nematodes (20 and 12 species per lake, some of them the same as in our material). Cyclopoids (4 species), ostracods (only Cyclocypris ovum), and harpacticoids (Canthocamptus staphylinus) were also found in appreciable numbers. Pseudomeiobenthos was formed of chironomid larvae (7 taxa) and oligochaetes. Most taxa of all groups occurred only in the shallowest zones, at 1-2 $\mathrm{m}$. The highest numbers of abundance and biomass were also registered on shallows: in Lake Pionerskoe, 140000 ind. $\mathrm{m}^{-2}$ at a depth of $2 \mathrm{~m}$ and $3.07 \mathrm{~g} \mathrm{~m}^{-2}$ at $1 \mathrm{~m}$ in July 1997; and in Lake Pridorozhnoe 21000 ind. $\mathrm{m}^{-2}, 0.6 \mathrm{~g} \mathrm{~m}^{-2}$ at $1 \mathrm{~m}$ in May. At a depth of $4 \mathrm{~m}$ far fewer taxa were found in both lakes, while the abundance and biomass were lower only in Lake Pionerskoe (yearly averages being 60800 ind. $\mathrm{m}^{-2}, 1.46 \mathrm{~g} \mathrm{~m}^{-2}$ at $2 \mathrm{~m}$, but 18400 ind. $\mathrm{m}^{-2}$ and $0.17 \mathrm{~g} \mathrm{~m}^{-2}$ at $4 \mathrm{~m})$. In Lake Pridorozhnoe no essential differences were observed between the abundances at 2 and $4 \mathrm{~m}\left(4800\right.$ and 3800 ind. $\left.\mathrm{m}^{-2}\right)$, while the biomass appeared to be, due to oligochaetes, even higher in the latter case $\left(0.07\right.$ and $0.31 \mathrm{~g} \mathrm{~m}^{-2}$, respectively). At $8 \mathrm{~m}$ in Lake Pionerskoe, an abundant diverse fauna consisting mostly of "small" animals (nematodes, ostracods, cyclopoids, harpacticoids) occurred, a total of 48000 ind. $\mathrm{m}^{-2}, 0.92 \mathrm{~g} \mathrm{~m}^{-2}$; but only in May. In June and later on, this zone was devoid of any macroscopic life, as was the case in Lake Pridorozhnoe in all seasons.

Thus in both lakes, Pionerskoe and Pridorozhnoe, meiobenthos was rich at depths of 1-2 $\mathrm{m}$, somewhat poorer at $4 \mathrm{~m}$ (corresponding possibly to the layer of the metalimnion in the water column), and lacking or only temporarily present at $8 \mathrm{~m}$. The year 1995 appeared to be poorer in meiobenthos than the two following years for both lakes. Seasonal changes varied significantly among different zones and lakes, with minima occurring in all months from May to October. The share of eumeiobenthos, especially that of small nematodes, was much larger than in the Estonian lakes studied in this paper. Cyclopoids were not so prevailing as in our lakes, while ostracods and harpacticoids were more common. Calanoids and cladocerans were not mentioned at all (possibly ignored as planktonic animals). A situation, common in Estonia, where a large number of cyclopoids alone form a meiobenthos sample from the zone of the hypolimnion, was not observed in these lakes, although there occurred the same cyclopoid species. The yearly abundance and biomass of meiobenthos there in different years (7900-61 600 ind. $\mathrm{m}^{-2}$, $0.38-1.85 \mathrm{~g} \mathrm{~m}^{-2}$ in Pionerskoe, and $2500-22300$ ind. $\mathrm{m}^{-2}, 0.08-0.41 \mathrm{~g} \mathrm{~m}^{-2}$ in Pridorozhnoe) were comparable to our data of the "small" animals in lakes Peta, Holstre, Tsolgo Mustjärv, or Kooraste Linajärv. Our Lake Holstre Linajärv would be considerably poorer and Lake Verevi richer, especially in "large" taxa in the latter case. 
Six lakes in eastern Latvia (Kurashov \& Belyakov, 1987) revealed a picture of meiobenthos (0.3-3 mm long animals were treated) comparable to that observed in Estonia. High numbers of abundance and biomass were recorded for the littoral of different lakes, from 21920 to 147070 ind. $\mathrm{m}^{-2}$ and from 0.75 to $5.43 \mathrm{~g} \mathrm{~m}^{-2}$, with higher numbers registered for more eutrophied lakes. On the contrary, in the profundal mainly cyclopoids occurred, accompanied by some other animals only in the cleanest lake. The abundance and biomass of meiobenthos in the profundal of individual lakes were $26350-167280$ ind. $\mathrm{m}^{-2}$ and $0.68-3.66 \mathrm{~g} \mathrm{~m}^{-2}$, respectively, the highest numbers recorded for the cleanest lake. No such distinct trend was observed for the Estonian lakes.

Babitskij (1980) gives a survey of the "microzoobenthos" of three Belarus lakes - Naroch, Myastro, and Batorin. The animals with a length less than $3 \mathrm{~mm}$ were treated, including Rotatoria and Testamoebae. All in all, 198 taxonomic units were recorded. Both abundance and biomass were higher in 1970 than in the following year, 1971, in all three lakes. Owing to the inclusion of the smallest animals, the abundance numbers exceed the Estonian data by about two orders of magnitude, while the biomass is on the same level as that of the "small" animals of our lakes. The richest "microzoobenthos" was recorded in moderately eutrophic Lake Myastro (two-year averages 1450000 ind. $\mathrm{m}^{-2}, 3.83 \mathrm{~g} \mathrm{~m}^{-2}$ ), followed by strongly eutrophic Lake Batorin (550 000 ind. $\mathrm{m}^{-2}, 1.62 \mathrm{~g} \mathrm{~m}^{-2}$ ) and mesotrophic Lake Naroch (314 000 ind. $\mathrm{m}^{-2}, 1.21 \mathrm{~g} \mathrm{~m}^{-2}$ ). Only sandy bottom supported a diverse fauna, while profundal mud was inhabited mainly by testamoebes and cyclopoids. Migration of cyclopoids from the water column into mud for winter dormancy caused an autumnal maximum of meiobenthos while another, summer maximum in June-July, was built by cladocerans, chironomids, and oligochaetes.

Another example of a seasonal cycle of "microbenthos" was described from deep mesotrophic Lake Glubokoe in Central Russia (Shcherbakov, 1955). Only two groups formed meiobenthos in our sense there: Nematoda in the shallower zone up to $6 \mathrm{~m}$, and Cyclopoida with the single species Cyclops strenuus in the profundal, with a maximum at depths of 15-20 m. Both taxa were virtually lacking in winter; nematodes appeared in May and copepods in June. The maxima of both groups, although low in comparison with those observed in other lakes, occurred in September: up to 6500 ind. $\mathrm{m}^{-2}, 0.1 \mathrm{~g} \mathrm{~m}^{-2}$ for the nematodes, and up to 3000 ind. $\mathrm{m}^{-2}, 0.6 \mathrm{~g} \mathrm{~m}^{-2}$ for the cyclopoids. The cyclopoids seem to have a oneyear life cycle there, with copepodite larvae occurring only in summer and adults in autumn. As macrobenthos in Lake Glubokoe is poor, the cyclopoids formed $11-35 \%$ of the total biomass in September 1950.

In three Masurian lakes, northeastern Poland, "microbenthos" (here 0.5-3.5 mm long animals) was studied by Stańczykowska \& Przytoka-Jusiak (1968). The lakes of Mikołajskie, Tałtovisko, and Śniardwy lie at the same latitude as the above-described Belarus lakes, but they are either holo- or polymictic, not so persistently stratified. They were repeatedly sampled in the ice-free period of 1963 and 1964, from $4 \mathrm{~m}$ to maximum depths. The smaller depths revealed a more 
diverse fauna dominated by chironomids, oligochaetes, and ostracods. At medium depths, nematodes prevailed in spring and summer and cyclopoids in autumn and, particularly, in winter. At maximum depths, cyclopoids formed virtually the whole meiofauna, reaching sometimes abundances up to 200000 ind. $\mathrm{m}^{-2}$ in winter and spring. A summer minimum (in July-August) and an autumnal or winter maximum of the total fauna were common. Among individual lakes, the shallowest Lake Śniardwy was characterized by the lowest numbers of abundance and biomass (on average 20000-30000 ind. $\mathrm{m}^{-2}, 0.8-2.4 \mathrm{~g} \mathrm{~m}^{-2}$ ), followed by Lake Tałtovisko $\left(10000-50000\right.$ ind. $\mathrm{m}^{-2}, 2.0-4.2 \mathrm{~g} \mathrm{~m}^{-2}$ ) and Lake Mikołajskie (40 000 ind. $\mathrm{m}^{-2}, 4.3-8.0 \mathrm{~g} \mathrm{~m}^{-2}$ ).

Stańczykowska (1967) described "zoomicrobenthos" from ten lakes of different types in northeastern Poland. Copepoda accounted for 20-75\% of the abundance, while eumeiobenthic animals were usually scarce as in our material. Only in deep oligotrophic Lake Háncza, Nematoda formed about half of all individuals. The average abundance of animals varied from several thousands per $\mathrm{m}^{2}$ in oligotrophic and dystrophic lakes up to 50000 ind. $\mathrm{m}^{-2}$ in mesotrophic lakes and to 73400 ind. $\mathrm{m}^{-2}$ in a polymictic eutrophic lake. Abundances decreased gradually towards larger depths. The biomass of "microzoobenthos" varied from a few fractions to several grams per $\mathrm{m}^{2}$, being always several times (up to 20 times in a dystrophic lake) less than that of macrozoobenthos in the same lakes.

Mikhajlov $(1970,1973)$ treated the "microbenthos" (in fact, meiobenthos) of large unstratified Lake Pihkva (Pskovskoe) on the border of Russia and Estonia. A diverse fauna inhabited the sandy bottom, while small chironomids and oligochaetes prevailed on mud. The average abundance for the whole lake in July 1967 was 56100 ind. $\mathrm{m}^{-2}$, and the biomass without larger, macrobenthic, animals was $5.47 \mathrm{~g} \mathrm{~m}^{-2}$, which is comparable to the respective figures for the richest small lakes of our study.

In even larger, very deep oligo-mesotrophic Lake Ladoga, at least 185 taxa of pseudo- and eumeiobenthos have been recorded (Kurashov, 1994). The majority of them occur in shallows with active currents and sandy bottom, reaching much larger depths there than in any small lake. Deeper than $160 \mathrm{~m}$, only several oligochaetes, two ostracods, three cyclopoids, and one harpacticoid remain in the fauna, none of them bound to these depths. The average abundance of meiobenthos in the open region of Lake Ladoga was $58250 \pm 5700$ ind. $\mathrm{m}^{-2}$ and average biomass $0.868 \pm 0.166 \mathrm{~g} \mathrm{~m}^{-2}$.

Smaller lakes of Sweden and Finland are not so strongly stratified as the Estonian ones either. Hence diverse meiobenthos can occur at large depths there, although the main animal groups are the same as in Estonian lakes (Milbrink, 1969; Paasivirta \& Särkkä, 1978).

The Estonian small lakes under study are all strongly stratified; only the layer of the epilimnion (corresponding roughly to the littoral zone of bottom) is well supplied with dissolved oxygen. Prolonged periods of anoxia have almost exterminated eumeiobenthic animals from the profundal (the zone covered with the water of the hypolimnion), even in the most oligotrophic lake of Nohipalu 
Valgjärv. This lake has still maintained a cold-preferring nematode species, Paramononchus alimovi, in its profundal. An unidentified harpacticoid species in Lake Tsolgo Mustjärv serves as another example of relicts of the formerly richer deep-water eumeiobenthos of Estonian small lakes. Some other eumeiobenthic taxa living also in the littoral can periodically colonize deeper zones when conditions permit this, such as Ostracoda in Lake Pindi Kärnjärv, both Ostracoda and Nematoda in Lake Verevi, or various groups (after Petukhov, 1999) in Lake Pionerskoe of the neighbouring Leningrad Region.

A temporary disturbance of the ecosystem in Lake Verevi caused an explosive increase in the diversity and abundance in the littoral and, partially, in the transition zone between the littoral and the profundal (the zone of the metalimnion). The profundal itself remained that time anoxic, unsuitable for most animal groups. However, the cyclopoids, dominated by Mesocyclops leuckarti, seemed to benefit there by the lake's disturbance.

A mass appearance of cyclopoids, particularly Mesocyclops leuckarti, in the anoxic profundal of lakes has been observed by many authors. Usually, this was explained by a passive resting period, for example hibernation at the copepodite stage, in sediment (Borutskij, 1950; Dahms, 1995; Winder et al., 2000, and many others). However, already Ulomskij (1953) demonstrated the high ecological variability of this species in different lakes. Milbrink (1969) found fully active Cyclops sp. in a mud core taken from Lake Mälaren in February. More recently, Papinska (1984) discovered a complicated life cycle of M. leuckarti in Lake Mikołajskie, including three different generations: with a short winter diapause, with a long summer diapause, and without any diapause. Both young and adult individuals tended to concentrate near and inside sediment even when active. Nilssen \& Wærvågen (2000) confirmed the presence of different life cycles in M. leuckarti and Thermocyclops oithonoides $(=$ M. oithonoides) in different climatic zones, including various number of generations, as well as both passive and active hibernation in mud. They also found that adult egg-bearing females tend to search for shelter near bottom. Our regular findings of young and adult cyclopoids in summer corer samples from Estonian small stratified lakes support the suggestion of their possible lingering near or inside mud at all life stages.

\section{ACKNOWLEDGEMENTS}

The author is greatly indebted to Dr. Henn Timm for taking the samples, as well as to several colleagues listed above for the identification of some animal groups. Mrs. Ester Jaigma kindly revised the English text of the paper. All the work was conducted within project No. 370208s98 of the Institute of Zoology and Botany "The influence of stratification on the circulation of biological matter in the lake ecosystem" supported with grant No. 3579 of the Estonian Science Foundation. 


\section{SPECIES LIST WITH THE NUMBER OF FINDINGS IN THE CORER SAMPLES FROM 10 LAKES, 1998-2001}

E, epilimnion; $\mathrm{M}$, metalimnion; $\mathrm{H}$, hypolimnion;

$\mathrm{P}$ (Lake Verevi only), profundal

Chironomidae (at least 24 larval forms):

Chironomini indet.

Chironomus plumosus

Chironomus sp. indet.

Cladopelma gr. viridula

Cladotanytarsus gr. mancus

Cryptochironomus defectus

Cryptochironomus sp. indet.

Dicrotendipes sp. indet.

Einfeldia carbonaria

Endochironomus impar

Glyptotendipes glaucus

Glyptotendipes paripes

Glyptotendipes sp. indet.

Microchironomus tener

Microtendipes pedellus

Parachironomus arcuatus

Paratanytarsus confusus

Polypedilum bicrenatum

Polypedilum cultellatum

Polypedilum tetracrenatum

Procladius choreus

Procladius ferrugineus

Procladius sp. indet.

Psilotanypus rufovittatus

Tanypus kraatzi

Tanypus vilipennis

Tanypus sp. indet.

Tanytarsus holochlorus/volgensis/occultus

Tanytarsus medius

Tanytarsus verralli

Tanytarsus sp. indet.

$$
\begin{aligned}
\mathrm{E}+2 \mathrm{M} & =3 \\
2 \mathrm{H} & =2 \\
2 \mathrm{E}+2 \mathrm{H} & =4 \\
\mathrm{E}+2 \mathrm{M}+\mathrm{H} & =4 \\
6 \mathrm{E}+2 \mathrm{M}+\mathrm{H} & =9 \\
\mathrm{E}+\mathrm{M} & =2 \\
\mathrm{E} & =1 \\
\mathrm{E} & =1 \\
2 \mathrm{E}+\mathrm{M} & =3 \\
\mathrm{E} & =1 \\
3 \mathrm{E}+\mathrm{M} & =4 \\
2 \mathrm{E}+\mathrm{H} & =3 \\
\mathrm{E}+\mathrm{M} & =2 \\
\mathrm{E} & =1 \\
\mathrm{E}+\mathrm{M} & =2 \\
\mathrm{H} & =1 \\
\mathrm{E} & =1 \\
\mathrm{M} & =1 \\
\mathrm{E} & =1 \\
\mathrm{H}+\mathrm{H} & =4 \\
\mathrm{M} & =1 \\
3 \mathrm{E}+4 \mathrm{M} & =7 \\
4 \mathrm{E}+\mathrm{M}+\mathrm{H} & =6 \\
\mathrm{E} & =1 \\
2 \mathrm{M} & =2 \\
2 \mathrm{E} & =6 \\
\mathrm{E} & =1 \\
2 \mathrm{E} & =2 \\
\mathrm{E} & =1 \\
\mathrm{E}+\mathrm{M}+\mathrm{M} & =11
\end{aligned}
$$

Oligochaeta (at least 30 species):

Amphichaeta leydigi

$\mathrm{E}=1$

Aulodrilus limnobius

$\mathrm{E}=1$ 
Aulodrilus pigueti

Chaetogaster diaphanus

Chaetogaster diastrophus

Dero digitata

Ilyodrilus templetoni

Limnodrilus hoffmeisteri

Limnodrilus udekemianus

Lumbriculus variegatus

Marionina riparia

Nais barbata

Nais communis

Nais pardalis

Nais pseudobtusa

Nais simplex

Nais variabilis

Ophidonais serpentina

Peipsidrilus saamicus?

Potamothrix hammoniensis

Pristina longiseta

Pristina aequiseta $\mathrm{f}$. foreli

Psammoryctides barbatus

Slavina appendiculata

Specaria josinae

Stylaria lacustris

Tubifex tubifex

Tubificidae indet.

Uncinais uncinata

Vejdovskyella macrochaeta

Vejdovskyella comata

Mollusca (at least 3 species):

Pisidiidae indet.

Anisus albus

Bithynia tentaculata

Ephemeroptera (at least 3 species):

Caenis horaria

Caenis luctuosa

Caenis sp. indet.

Cloeon sp. indet.

Trichoptera (at least 3 species):

Cyrnus sp.

Leptocerus tineiformis

Oxyethira sp. indet.

Trichoptera indet.

$$
\begin{aligned}
\mathrm{M} & =1 \\
2 \mathrm{E}+3 \mathrm{M} & =5 \\
3 \mathrm{E} & =3 \\
4 \mathrm{E}+3 \mathrm{M} & =7 \\
\mathrm{E}+\mathrm{M} & =2 \\
9 \mathrm{E}+9 \mathrm{M}+\mathrm{H}=19 & =2 \\
\mathrm{E} & =1 \\
2 \mathrm{E} & =2 \\
2 \mathrm{E} & =2 \\
\mathrm{E} & =1 \\
2 \mathrm{E} & =2 \\
\mathrm{E} & =1 \\
\mathrm{E} & =1 \\
\mathrm{M} & =1 \\
\mathrm{E}+\mathrm{M} & =2 \\
\mathrm{H} & =1 \\
\mathrm{M}+6 \mathrm{H} & =33 \\
2 \mathrm{E}+\mathrm{M} & =3 \\
3 \mathrm{E}+2 \mathrm{M} & =5 \\
\mathrm{E} & =1 \\
2 \mathrm{M} & =2 \\
2 \mathrm{E}+\mathrm{M} & =3 \\
\mathrm{E}+3 \mathrm{M} & =4 \\
3 \mathrm{E}+2 \mathrm{H} & =5 \\
\mathrm{M} & =1 \\
2 \mathrm{E}+5 \mathrm{M} & =7 \\
2 \mathrm{E} & =2 \\
\mathrm{E}+\mathrm{M} & =2 \\
\mathrm{E} & \\
\mathrm{E}+\mathrm{M} & =2 \\
\mathrm{E}+4 \mathrm{M} & =12 \\
\mathrm{E} & =1 \\
\mathrm{E} & =1 \\
\mathrm{E} & =1 \\
\mathrm{E} & =3 \\
\mathrm{E}+\mathrm{M} & =2 \\
2 \mathrm{E} & =1 \\
& =1 \\
5 \mathrm{E} & =1 \\
\mathrm{E} & =1
\end{aligned}
$$


Other macrozoobenthos (6 taxa):

Ceratopogonidae indet.

$$
\begin{aligned}
& 4 \mathrm{E}+2 \mathrm{M}+2 \mathrm{H}=8 \\
& 2 \mathrm{M}+6 \mathrm{H}+5 \mathrm{P}=13 \\
& \mathrm{M}=1 \\
& \mathrm{M}=1 \\
& 2 \mathrm{E}+2 \mathrm{M}=4 \\
& 3 \mathrm{E}+\mathrm{M}+\mathrm{H}=5 \\
& \mathrm{E}=1 \\
& \mathrm{E}=1 \\
& \mathrm{E}=1
\end{aligned}
$$

Chaoborus flavicans

Sialis lutaria

Asellus aquaticus

Hydracarina indet.

Alboglossiphonia heteroclita

Cristatella mucedo

Mermithidae indet.

Small Nematoda (at least 8 species):

Actinolaimidae gen. sp. indet.

Brevitobrilus stefanskii

Dorylaimus stagnalis

Ironus ignavus

Neotobrilus longus

Paramononchus alimovi

Tobrilus gracilis

Tripyla glomerans

Nematoda indet.

Turbellaria indet.

Hydra sp. indet.

Ostracoda (at least 12 species):

Candona acuminata

$$
\mathrm{E}=1
$$

$\mathrm{E}+\mathrm{H}=2$

$\mathrm{E}=1$

$\mathrm{E}=1$

$\mathrm{E}=1$

$2 \mathrm{H}=2$

$2 \mathrm{H}=2$

$2 \mathrm{E}=2$

$8 \mathrm{E}+3 \mathrm{M}+\mathrm{H}=12$

$8 \mathrm{E}+\mathrm{M}=9$

$2 \mathrm{E}+\mathrm{M}=3$

Candona albicans

Candona candida

Candona fragilis

Candona protzi

Candona sp.

Cyclocypris laevis

Cypria curvifurcata

Cypria ophthalmica

Cypridopsis vidua

Cytherissa lacustris

Dolecypris fasciata

Ilyocypris? sp. indet.

Ostracoda indet.

$$
\begin{aligned}
M & =1 \\
M & =1 \\
2 E+2 M & =4 \\
1 E+1 M & =2 \\
E+M & =2 \\
2 E+H & =(4) \\
E & =1 \\
E & =1 \\
2 & =4 \\
2 \mathrm{H}+\mathrm{P} & =4 \\
\mathrm{E}+\mathrm{M} & =4 \\
\mathrm{E}+\mathrm{M}+\mathrm{H} & =2 \\
\mathrm{E} & =1 \\
\mathrm{M} & =1 \\
2 \mathrm{E}+\mathrm{M}=(3) & \\
2 \mathrm{E}+2 \mathrm{M} & =4 \\
\mathrm{E} & =1 \\
\mathrm{E}+\mathrm{M} & =2
\end{aligned}
$$

Cladocera (at least 17 species):

Alona affinis

Alona costata

Alona quadrangularis 
Alona rectangula

Alona sp. indet.

Acroperus harpae

Bosmina coregoni

Camptocercus rectirostris

Ceriodaphnia pulchella

Ceriodaphnia sp. indet.

Daphnia cucullata (+galeata?)

Daphnia longispina

Daphnia sp. indet.

Diaphanosoma brachyurum

Eurycercus lamellatus

Graptoleberis testudinaria

Holopedium gibberum

Leydigia leydigi

Leydigia sp. indet.

Pleuroxus uncinatus

Simocephalus vetulus

Cladocera indet.

Calanoida (at least 2 species):

Eudiaptomus gracilis

Eudiaptomus graciloides

Eudiaptomus sp. indet.

Calanoida indet.

Cyclopoida (at least 7 species):

Mesocyclops leuckarti

Mesocyclops oithonoides

Mesocyclops sp. indet.

Acanthocyclops viridis

Eucyclops sp. indet.

Macrocyclops albidus

Macrocyclops sp. indet.

Microcyclops? sp. indet.

Cyclops sp. indet.

Cyclopoida indet.

Harpacticoida indet.

$$
\begin{aligned}
& \mathrm{E}=1 \\
& \mathrm{E}+\mathrm{M}=(1) \\
& \mathrm{E}+\mathrm{M}=2 \\
& \mathrm{H}=1 \\
& \mathrm{E}=1 \\
& \mathrm{E}=1 \\
& \mathrm{E}+2 \mathrm{M}+\mathrm{H}=(3) \\
& \mathrm{H}+\mathrm{P}=2 \\
& \mathrm{H}=1 \\
& \mathrm{H}=(1) \\
& 3 \mathrm{E}+\mathrm{M}+\mathrm{P}=5 \\
& 2 \mathrm{E}=2 \\
& \mathrm{E}=1 \\
& \mathrm{E}+\mathrm{M}+\mathrm{H}=3 \\
& \mathrm{E}=1 \\
& \mathrm{E}=(1) \\
& \mathrm{E}+\mathrm{M}+\mathrm{H}=3 \\
& 2 \mathrm{E}+2 \mathrm{M}=4 \\
& 2 \mathrm{E}+4 \mathrm{M}+2 \mathrm{H}=(8) \\
& \mathrm{E}+2 \mathrm{M}+\mathrm{H}=4 \\
& \mathrm{E}+2 \mathrm{M}+3 \mathrm{H}+3 \mathrm{P}=9 \\
& 3 \mathrm{E}+\mathrm{M}+3 \mathrm{H}=(7) \\
& \mathrm{E}+3 \mathrm{M}+4 \mathrm{H}+\mathrm{P}=(9)
\end{aligned}
$$

$$
\begin{array}{r}
13 \mathrm{E}+8 \mathrm{M}+10 \mathrm{H}+5 \mathrm{P}=36 \\
3 \mathrm{E}+3 \mathrm{M}+\mathrm{H}=7 \\
2 \mathrm{M}+\mathrm{H}=(3) \\
3 \mathrm{E}+2 \mathrm{M}=5 \\
2 \mathrm{E}+3 \mathrm{M}+3 \mathrm{H}=8 \\
\mathrm{H}=1 \\
\mathrm{M}=(1) \\
\mathrm{M}=1 \\
\mathrm{M}+2 \mathrm{H}=3 \\
\mathrm{M}+\mathrm{H}=2
\end{array}
$$

Total: at least 120 taxa, including 71 macrozoobenthic taxa and 49 taxa belonging to eumeiobenthos and plankton 


\section{REFERENCES}

Babitskij, V. A. 1980. Microzoobenthos in three lakes of different types. Gidrobiol. zh., 16, 1, 37-45 (in Russian).

Borutskij, E. V. 1950. Seasonal vertical distribution of planktonic Copepoda in the water mass of Lake Beloe in Kosino at the different stages of development. Zool. zh., 29, 2, 120-127 (in Russian).

Dahms, H. U. 1995. Dormancy in Copepoda - an overview. Hydrobiologia, 306, 199-211.

Elmgren, R. 1973. Methods of sampling sublittoral soft fauna. Oikos, Suppl., 15, 112-120.

Higgins, R. P. \& Thiel, H. 1988. Introduction to the Study of Meiofauna. Smithsonian Institution Press, Washington D.C. \& London.

Järvekülg, A. 1979. Bottom Fauna of the Eastern Part of the Baltic Sea. Valgus, Tallinn (in Russian).

Kurashov, E. A. 1994. Meiobenthos as a Component of Lake Ecosystem. Institute of Limnology of RAS, St. Petersburg (in Russian).

Kurashov, E. A. \& Belyakov, V. P. 1987. Role of meiofauna in benthic community in the Latvian lakes of different type. Gidrobiol. zh., 23, 2, 46-50 (in Russian).

Mikhajlov, A. E. 1970. Oligochaetes in the microbenthos of Lake Pskov. In Biological Processes in the Marine and Continental Water Bodies. Abstracts of the II Congress of the All-Union Hydrobiological Society, p. 269. Kishinev (in Russian).

Mikhajlov, A. E. 1973. On the microbenthos of Lake Pskov. In Biological Researches on the Baltic Inland Water Bodies. Proceedings of the XV Scientific Conference on the Baltic Inland Water Bodies, pp. 73-75. Minsk (in Russian).

Milbrink, G. 1969. Microgradients at the mud-water interface. Rep. Inst. Freshwater Res., Drottningholm, 49, 129-148.

Nilssen, J. P. \& Wærvågen, S. B. 2000. Superficial ecosystem similarities vs autecological stripping: the "twin species" Mesocyclops leuckarti (Claus) and Thermocyclops oithonoides (Sars) - seasonal habitat utilisation and life history traits. J. Limnol., 59, 2, 79-102.

Paasivirta, L. \& Särkkä, J. 1978. Effects of pulp mill and municipal effluents and humus load on the macro- and meiozoobenthos of some Finnish lakes. Verh. Int. Ver. Limnol., 20, 1779-1788.

Papinska, K. 1984. The life cycle and the zones of occurrence of Mesocyclops leuckarti Claus (Cyclopoida, Copepoda). Ekol. pol., 32, 493-531.

Petukhov, V. A. 1999. Vertical distribution of meiobenthos in the lakes of Pionerskoe and Pridorozhnoe in Leningrad Region, 1997. In Structural-functional Organization of Freshwater Ecosystems of Different Type. Tr. Zool. inst. RAN, 279, 222-235 (in Russian).

Särkkä, J. 1992. Lacustrine profundal meiobenthos as an environmental indicator. Hydrobiologia, 243/244, 333-340.

Särkkä, J. 1993. Diversity of meiofauna in the lacustrine profundal zone: bathymetric differences and influence of environmental factors. Aquat. Sci., 55/3, 197-205.

Särkkä, J. 1995. Profundal meiofauna in two large lakes: influence of pollution and bathymetric differences. Arch. Hydrobiol., 132, 4, 453-493.

Särkkä, J. 1999. Species-level and group-level meiofaunal data as environmental indicators in the lake profundal zone: a review. In Biodiversity in Benthic Ecology. Proceedings from Nordic Benthological Meeting in Silkeborg, Denmark, 13-14 November 1997 (Friberg, N. \& Carl, J. D., eds). National Environmental Research Institute, Denmark. NERI Technical Report, 266, 127-131.

Shcherbakov, A. P. 1955. Dynamics in the abundance and biomass of some representatives of microbenthos in Lake Glubokoe. Tr. Vsesoyuz. gidrobiol. obshch., 6, 122-132 (in Russian).

Skvortsov, V. V. 1984. Quantitative evaluation of the meiobenthic community in the processes of organic matter transformation in the lacustrine ecosystems. Sb. nauchn. tr. GosNIORKh, 223, 108-111 (in Russian). 
Smit, H., Dudok van Heel, E. \& Wiersma, S. 1993. Biovolume as a tool in biomass determination of Oligochaeta and Chironomidae. Freshwater Biol., 29, 1, 37-46.

Stańczykowska, A. 1967. Comparison of the zoomicrobenthos occurring in the profundal of several lakes in Northern Poland. Bull. Acad. pol. Sci., classe II, 15, 349-353.

Stańczykowska, A. \& Przytoka-Jusiak, M. 1968. Variations in abundance and biomass of microbenthos in three Mazurian lakes. Ekol. pol., 16, 27, 539-559.

Timm, H., Möls, T. \& Timm, T. (in press) Macro- and meiobenthos in some small stratified lakes of Estonia. In Symposium of the Nordic Benthological Society, Lake Mývatn, 13-16 May 2001.

Ulomskij, S. N. 1953. New data on the ecology of some species of copepod crustaceans (Copepoda) - Mesocyclops leuckarti (Claus), 1857. Dokl. Akad. Nauk SSSR, 90, 2, 295-297 (in Russian).

Winder, M., Pehofer, H. E. \& Füreder, L. 2000. Distribution patterns of benthic crustaceans in a formerly meromictic lake with changing trophic conditions (Lake Piburg, Tyrol, Austria). Arch. Hydrobiol., 147, 4, 519-533.

Zakhodnova, T. A., Petukhov, V. A. \& Alekseev, V. P. 1984. Consumption of the production of microphytobenthos by meiobenthos and protozoans in the littoral of Lake Verkhnee Vrevo (according to the data from 1982). Sb. nauchn. tr. GosNIORKh, 224, 87-97 (in Russian).

\section{Mõnede Eesti kihistunud väikejärvede meiobentos}

\section{Tarmo Timm}

Kümnest järvest koguti aastail $1998-1999$ toruammuti abil $\left(6,38 \mathrm{~cm}^{2}\right)$ põhjaloomade proove kolmest punktist litoraali ja profundaali üleminekualal, vee hüppekihi kohal ja lähedal, Verevi järvest võeti proove lisaks ka aastail 20002001. Proovid pesti peenel sõelal $(0,15 \mathrm{~mm})$ ja sorteeriti binokulaarmikroskoobi all. 120 leitud taksoni seas oli kõige rohkem makrozoobentose loomade väiksemaid (harva ka suuri) isendeid ja planktonvähke; eumeiobentose loomade (Nematoda, Turbellaria, Hydra, Ostracoda, Harpacticoida) osatähtsus oli väga väike. Võrreldes tavaliste, põhjaammutiga võetud proovidega oli loomade keskmine arvukus meiobentoseproovides suurusjärgu võrra suurem, aga nende biomass oluliselt ei erinenud. Loomade arvukus, biomass ja liigiline mitmekesisus kahanesid üldiselt sügavuse suurenedes; ainult planktilisi sõudikulisi (Cyclopoida), kes veedavad osa oma elust hapnikuvaese põhjasette sees või lähedal, oli kõige enam sügaval. Hüppekihti eelistavaid loomi ei leitud. Verevi järve põhjaloomastik oli erakordselt vormi- ja isendirikas aastail 1999-2000, kui ehitati ujulat ja muudeti veetaset; aastaks 2001 taastus varasem olukord. 